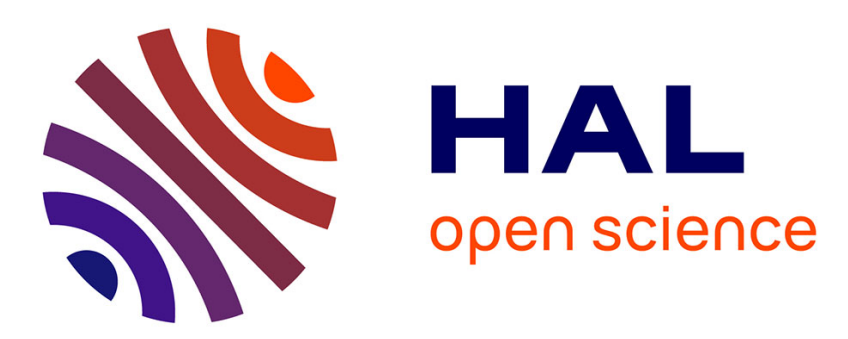

\title{
Empirical correction of XBT fall rate and its impact on heat content analysis
}

\author{
M. Hamon, Pierre-Yves Le Traon, Gilles Reverdin
}

\section{To cite this version:}

M. Hamon, Pierre-Yves Le Traon, Gilles Reverdin. Empirical correction of XBT fall rate and its impact on heat content analysis. Ocean Science Discussions, 2011, 8, pp.291-320. 10.5194/OSD-8-291-2011 . hal-00755109

\section{HAL Id: hal-00755109 \\ https://hal.science/hal-00755109}

Submitted on 2 Dec 2015

HAL is a multi-disciplinary open access archive for the deposit and dissemination of scientific research documents, whether they are published or not. The documents may come from teaching and research institutions in France or abroad, or from public or private research centers.
L'archive ouverte pluridisciplinaire HAL, est destinée au dépôt et à la diffusion de documents scientifiques de niveau recherche, publiés ou non, émanant des établissements d'enseignement et de recherche français ou étrangers, des laboratoires publics ou privés. 
Ocean Sci. Discuss., 8, 291-320, 2011

www.ocean-sci-discuss.net/8/291/2011/

doi:10.5194/osd-8-291-2011

(c) Author(s) 2011. CC Attribution 3.0 License.
OSD

8, 291-320, 2011

Empirical correction of XBT fall rate and its impact on heat content analysis

M. Hamon et al.

\section{Title Page}

Abstract

Conclusions

Tables

${ }^{1}$ Laboratoire d'Oceanographie Spatiale, IFREMER, B.P.70 Plouzane, France

${ }^{2}$ LOCEAN, 4 place Jussieu 75252 Paris, France

Received: 2 November 2010 - Accepted: 25 January 2011 - Published: 2 February 2011 Correspondence to: M. Hamon (mathieu.hamon@ifremer.fr)

Published by Copernicus Publications on behalf of the European Geosciences Union.

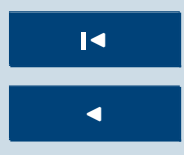

Back 


\section{Abstract}

We used a collocation method between XBT and CTD/OSD (Ocean Station Data including bottle cast and low resolution CTD) from WOD05 $\left(1^{\circ} \times 2^{\circ} \times 15\right.$ days $)$ to statistically correct the XBT fall rate. An analysis of the annual median bias on depth showed 5 that it is necessary to apply a thermal correction linked to probe calibration error, a second order correction on the depth as well as a depth offset representing measurement errors during XBT deployment. We had to separate data in several categories: shallow and deep XBT and deployment sea temperatures (below or above $10^{\circ} \mathrm{C}$ ). We also processed separately XBT measurements close to Japan between 1968 and 1985 due 10 to large regional biases. Once the corrections have been applied, the analysis of heat content signal is derived from corrected XBT. From this analysis, we confirm that the maximum heat content in the top 700 meters found during the 70 's in early papers can be explained by the XBT biases. In addition, a trend of $0.32 .10^{22} \mathrm{~J} /$ year is observed between the period 1970 and 2008.

\section{Introduction}

Identifying and quantifying the effects of global warming is one of the most important research areas for the international oceanographic community. Due to its heat capacity, much larger than the other elements of the climate system, it is estimated that the oceans have absorbed more than $80 \%$ of the earth warming due to the anthropogenic increase of greenhouse gas concentration (Levitus et al., 2001, 2005). In the last few years, many studies have tried to accurately determine the evolution of the global ocean heat content (e.g. Gouretski and Koltermann, 2007; Wijffels et al., 2008; Levitus et al., 2009). They observed biases between the different instruments used to collect ocean temperature profiles. Expendable BathyThermographs (XBT) have been mostly launched from underways ships since 1966 allowing the measurement of the upper ocean's temperature. The XBT system does not directly measure depth. The

\section{OSD}

8, 291-320, 2011

\section{Empirical correction of XBT fall rate and its impact on heat content analysis}

M. Hamon et al.

\section{Title Page}

\section{4}

Back

Close 
accuracy of the depth associated with each temperature depends on an equation which converts the time elapsed since the probe entered the water to depth. Gouretski and Koltermann (2007) used an ocean climatology based on high quality data (Conductivity Temperature Depth (CTD) and Nansen casts) to identify biases in XBT observations.

5 They found a positive bias by $0.2-0.4^{\circ} \mathrm{C}$ on average with some variations from year to year. Based on this study and further comparisons between data types, Wijffels et al. (2008) proposed a yearly linear correction on the depth (hereafter W08). More recently Levitus et al. (2009) used a simpler temperature correction, subtracting to all XBTs, the annual median temperature bias compared on a CTD climatology. Based 10 on these previous studies, Gouretski and Reseghetti (2010) proposed a new correction using a depth correction added to a temperature offset.

The W08 correction is a reference for the processing of XBT data but one can question whether this correction depends on the method of comparison between XBT and CTD profiles. A new more precise correction, correcting individually each type of XBT 15 cannot be envisioned but, is it also possible to refine the' W08 correction? The objective of this paper is to build a new correction based on the precise observation of the bias derived from colocated XBT and CTD/OSD data.

\section{Data and collocation method}

In the current study we used temperature profiles of the World Ocean Database 2005 20 (hereafter WOD05) where profiles have been interpolated to standard levels. The ocean was subdivided into 16 vertical levels from the surface to $700 \mathrm{~m}$ depth. We used profiles that have been processed when identification was possible using the correction H95 (Hanawa et al., 1995). Instead of using two climatologies, one constructed with CTD and bottles profiles, and the other with XBT profiles, we used a collocation method to compare instruments. We selected all CTD and OSD (Ocean Station Data) geographically distant by less than $1^{\circ}$ of latitude and $2^{\circ}$ of longitude and temporarily distant from less than 15 days. For each individual XBT profile, we calculated a reference

OSD

8, 291-320, 2011

\section{Empirical correction of XBT fall rate and its impact on heat content analysis}

M. Hamon et al.

\section{Title Page}


profile as the median of all CTD and OSD profiles selected in the region of collocation. The bias profile was then calculated by subtracting this reference profile from the XBT profile. Following Levitus et al. (2009) median rather than arithmetic average was used, as it reduces the influence of outliers. Moreover, we removed XBT profiles shallower 5 than $200 \mathrm{~m}$ depth to exclude coastal regions. This method allows us to retain about $10^{4}$ profiles a year between the year 1967 and 2007.

\section{Test of the W08 correction}

The W08 correction $A$ is a linear correction computing the "true" estimated XBT depth $Z_{\text {true }}$ from the depth $Z$ calculated with the original fall rate.

$10 Z_{\text {true }}=Z(1-A)$

W08 separated the deep XBT profiles (hereafter called XBTD) measuring temperature below $500 \mathrm{~m}$ (in standard levels) which are predominantly T7 or Deep Blue, and the others, shallow XBT profiles (hereafter called XBTS) which are predominantly T4 instruments. According to their study, W08 note a depth error near $400 \mathrm{~m}$ of $10 \mathrm{~m}$ for 15 XBTS and half that for XBTD on average.

We first applied the W08 correction to our collocated profiles. Figure 2 shows the yearly raw and W08 corrected median bias on depth as a function of year. According to Gouretski and Koltermann (2007) and Wijffels et al. (2008) there is a positive bias between vertically averaged XBT temperature and high quality data like CTD and OSD.

20 This median bias varies with the year of deployment of the XBT. It varies between $0.2^{\circ} \mathrm{C}$ and $0.1^{\circ} \mathrm{C}$ during the end of the $60^{\prime}$ 's until the beginning of the 80 's. Then the bias stabilizes around $0.05^{\circ} \mathrm{C}$. Moreover this evolution agrees with the results of Levitus et al. (2009).

The vertical median bias is not uniformly reduced while applying the W08 correction.
Obviously the linear correction does not correct the surface bias (Fig. 2). It can also be
OSD

$8,291-320,2011$

\section{Empirical correction of XBT fall rate and its impact on heat content analysis}

M. Hamon et al.

Title Page

Abstract Introduction

Conclusions

References

Tables

Figures

14

- I

4

Back

Close

Printer-friendly Version

Interactive Discussion 
sometimes too large and induce a negative bias. Our comparison method thus suggests that a linear correction is not sufficient to properly reduce the observed biases.

\section{Analysis of the XBT bias}

We will try to refine the model of bias correction by examining in more detail the vertical 5 and spatial structure of the XBT/CTD biases. The W08 correction does not properly reduce the global median bias of our XBT and CTD/OSD collocation. We begin to compare very close pairs with weak temperature gradients and we identify a thermal bias. This observation agrees well with the recent work of Gouretski and Reseghetti (2010). We then computed the median annual bias as a function of depth to adjust at a given 10 temperature the depth indicated by the original fall rate. We can linearly interpolate to retrieve the temperature at standard levels. We compute the depth bias at each standard level with the first order approximation,

$d Z=\left(T_{\mathrm{CTD}}-T_{\mathrm{XBT}}\right) \frac{\delta Z}{\delta T_{\mathrm{CTD}}}$

Our calculations of depth bias from collocated profiles points to several observations. 15 As in Wijffels et al. (2008), the behavior of XBTS and XBTD was different. Moreover, the collocated profiles do not seem to be corrected by a linear function, but rather by a parabolic function.

This parabolic character is more or less pronounced according to year, geographical area and the type of XBT. We thus computed a second order correction with a least square fitting process for all years of deployment and all classes of XBT made in this study. The bias on depth also has a different behavior in the first meters of the probe fall. Between the surface and $30 \mathrm{~m}$, the error deviates from its parabolic behavior, possibly due to the high variability of surface temperature added to low gradient of the surface mixed layer producing high variability in the calculated $d Z$ quantities.
OSD

8, 291-320, 2011

\section{Empirical correction of XBT fall rate and its impact on heat content analysis}

M. Hamon et al.

\section{Title Page}

\section{4}


On the other hand, there seems to be a correlation between depth bias and the temperature of the sea water where the probe had been deployed (Thadathil et al., 2002). Figure 3 shows the depth bias at $100 \mathrm{~m}$ as a function of average temperature between 0 and $200 \mathrm{~m}$ for XBTS (in red) and XBTD (in blue) averaged over the study 5 period. We notice an increase of the bias toward low temperatures, without finding a different behavior between the two classes of XBT. Although, Fig. 3 still illustrates the need to process XBTs in categories of temperatures, nothing clearly distinguishes XBTS from XBTD at this depth.

Comparing the bias at a given depth is not a suficient indicator as it is the behavior 10 of the depth error that is essential. Figure 5 represents the linear part $(A z)$ as a function of the parabolic part at $400 \mathrm{~m}$ depth $\left(B z^{2}\right)$ for a new correction for XBTS (circles) and XBTD (stars) at high temperature (left) and at low temperature (right). Each dial represents a different regime of the yearly median depth bias. Most profiles have to be corrected by a function having a negative parabolic part and a positive linear part.

15 This indicates that the fall rate equation of most XBT probes badly estimates the actual speed of fall in the first meters and tends to approach it at greater depth. At lower temperatures, the behavior of XBTS and XBTD fall is totally different. Particularly in the end of the 70's and the 90's, we notice that the parabolic part of the XBTD becomes positive and several profiles have a negative linear part. Furthermore, we note that

\section{A new correction}

Based on the previous analysis, we propose the following new correction for XBTs:

- Correction of thermal bias:

$$
T_{\mathrm{XBT}}=T_{\mathrm{XBT}}-T_{\text {off }}
$$

OSD

8, 291-320, 2011

\section{Empirical correction of XBT fall rate and its impact on heat content analysis}

M. Hamon et al.

\section{Title Page}

\section{4}

\section{Full Screen / Esc}

Printer-friendly Version

Interactive Discussion 
- Correction of the depth bias:

$$
Z_{\text {true }}=Z_{\text {obs }}\left(1-A-B Z_{\text {obs }}\right)-Z_{\text {off }}
$$

OSD

8, 291-320, 2011

\subsection{Thermal correction}

Errors on the calibration of the temperature probes can also be a source of bias. In 5 addition, as the XBTs are passive sensors, the possibility of parasites resistances or other circuit-dependent parameters can induce errors in the temperature data reported by the instrument. Comparing neighboring XBT and CTD/OSD profiles in the upper mixed layer, we observed a positive thermal bias between $10 \mathrm{~m}$ and $30 \mathrm{~m}$. Following Gouretski and Reseghetti (2010), we selected close profiles with a weak temperature gradient in the upper layer (less than $0.0025^{\circ} \mathrm{C} \mathrm{m}-1$ ). This criterium guarantees that the observed bias is not related to the estimation of the depth of the XBT probe but to a error of calibration.

As we did not find significant differences between profiles measured in high or low water temperature, we decided to separate them only in two categories. We compute 15 an offset $T_{\text {off }}$ related to XBTS and another for XBTD (Eq. 5, Table 1). The thermal offset associated with XBTS is largely positive between 1968 and $1980\left(0.069^{\circ} \mathrm{C}\right.$ in average) and tends to zero afterward. The thermal bias of XBTD is more constant. A maximum is reached before $1980\left(0.040^{\circ} \mathrm{C}\right.$ in average) which decreases during the 80 's and becomes again maximum at the end of the $90^{\prime} \mathrm{s}\left(0.047^{\circ} \mathrm{C}\right.$ in average between 201995 and 2005).

\subsection{Second order correction}

The parabolic character of the correction is certainly due to a too simple approximation of the XBT fall rate. Indeed, it is possible that the first XBT fall rates calculated by observation of the fall of a probe in a water tank were not adapted to forecast their behavior

\section{Empirical correction of XBT fall rate and its impact on heat content analysis}

M. Hamon et al.

Title Page

Abstract Introduction

Conclusions

References

Tables Figures

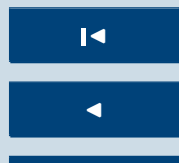

$>1$

Back

Close

Full Screen / Esc

Printer-friendly Version

Interactive Discussion 
in ocean water associated to variations of temperature and salinity. Furthermore, characteristics of probes can vary in time. The weight and all hydrodynamic parameters are essential to estimate the velocity of probes. According to Seaver and Kuleshov (1982), a weight uncertainty of $2 \%$ could induce $8.8 \mathrm{~m}$ of depth error at $750 \mathrm{~m}$. Gouretski and

5 Reseghetti (2010) find significant weight variations for probes manufactured after 1992 and we can easily extrapolate those results to earlier probes. All these error sources imply that the XBTs do not fall exactly as a second order equation of the time, and this equation might also change with time.

Following a global approach, we chose to differentiate several profile categories, 10 timally correct the database. This distinction allows us to have a sufficient number of To avoid discontinuities between profiles deployed in water close to $10^{\circ} \mathrm{C}$, we used an overlap. For the high temperatures class, we selected all XBTs deployed in water 15 warmer than $8^{\circ} \mathrm{C}$ and for the low temperature class, we selected XBTs deployed in water colder than $12^{\circ} \mathrm{C}$. We applied the process of depth correction three times because of the difficulty to exactly calculate the median depth bias, particularly in the areas of weak thermal gradients.

\subsection{Depth offset}

20 In spite of a good correlation between the median bias and its yearly correction, the resulting temperature bias is not zero, particularly in the surface layer. This is due to a median offset not corrected by the second order correction because it is poorly observed by our depth bias calculation involving the local gradient of temperature.

There is not a clear physical explanation for this offset, but it could result from human 25 mishandling. Probes launched from surface ships do not touch vertically the water surface and take time to sink at the assumed fall speed. Their initial velocity may also be questioned. The calculation of the drop height in board is very rough because of movements on the ocean surface as the swell or waves. All these phenomena prevent
OSD

8, 291-320, 2011

\section{Empirical correction of XBT fall rate and its impact on heat content analysis}

M. Hamon et al.

Title Page

Abstract Introduction

Conclusions

Tables

References

Figures

14

$>1$

4

Back

Close

Full Screen / Esc

Printer-friendly Version

Interactive Discussion 
us to accurately characterize a median offset. To overcome this lack of information, we opt for an empirical fitting proportionally adjusting the offset with the pre-corrected bias by the parabolic function. We used more exactly the yearly median depth error between $30 \mathrm{~m}$ and $200 \mathrm{~m}$ to statically correct the depth offset error. We chose to compute the 5 offset in this thin layer because it correponds to a compromise between the choice of a surface layer, where the calculation of a depth bias is not influenced by the fall rate error and the layer of maximum gradient.

$Z_{\text {off }}=<d Z>_{30-200}$

We note (Tables 3, 4, 5 and 6 ) that the depth offset can be negative for several years. 10 This could occur when the entry of the probe in water is detected late or if the speed of the probe at the impact in water is too high. In those cases the reported depth can be really deeper than the observed depth.

\subsection{Specific case}

After the global bias analysis by collocation, it is possible that residual biases identified or Gulf stream region, due to sampling issues. Measurements close to Japan and in the western Pacific basin (the northwest Pacific region bounded by $180^{\circ} \mathrm{E}$ and north of $20^{\circ} \mathrm{S}$ ) show a strong negative corrected bias appears during the period 1968/1985 after the global correction. We note a predominantly negative bias at $300 \mathrm{~m}$ depth (Fig. 6), which implies that these XBTs are poorly corrected by our global parabolic term. In this case, it is possible that the problem originates partially from specific XBT probes, but as we have not been able to identify them, this requires a specific regional correction. This distinction is particularly necessary because retaining these XBTs in the global dataset would have an impact on the estimated correction. Thus, we separated these regional profiles in another category, thus increasing the robustness of the global correction (Tables 7 and 8 ). The coefficients $A$ and $B$ calculated for these particular XBTS are quite similar to those calculated for XBTS deployed in high temperature, whereas 299
OSD

$8,291-320,2011$

\section{Empirical correction of XBT fall rate and its impact on heat content analysis}

M. Hamon et al.

Title Page

Abstract Introduction

Conclusions

Tables

References

Figures

14

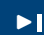

4

Back

Close

Printer-friendly Version

Interactive Discussion 
the coefficients for the XBTD in this region are very different from the others. The coefficient $A$ is largely positive in the first years and decreases until 1985 and $B$ is strongly negative and increases with time. The depth offset is also strong. This behavior is specific to those regional XBTD. The other difference is referred to the temperature offset 5 (Table 2). During the first years, the regional temperature offset is positive but not as strong as for the other XBTs (Table 1). From 1975 it becomes slightly negative.

\section{Calculation of the corrected heat content}

Following Wijffels et al. (2008) and Levitus et al. (2009), we also estimated a median depth bias on Mechanical BathyTermograph (MBT). The following figures result from 10 the correction of both XBTs and MBTs. Using the same methodology, we performed a second order correction added to an offset. We also separated MBT deployed at high and low temperatures. For those probes, the selected treshold was $12{ }^{\circ} \mathrm{C}$ for the median temperatures calculated between the surface and $100 \mathrm{~m}$ depth.

With the globally corrected database, we can easily map the observations on a lat15 itude and longitude grid $\left(4^{\circ} \times 8^{\circ}\right)$. The annual mean anomalies of temperature are obtained by subtracting the WOA05 climatology. We attributed to empty boxes the value of the annual mean anomaly of all full boxes. Figure 9 shows the $0-700 \mathrm{~m}$ integrated heat content calculated from the corrected XBT database (green), the raw XBT database (red), the entire WOD05 database (red) and the entire database where XBT and MBT have been corrected (blue).

The calculation of the corrected heat content suggests that the local warming observed during the 70's was the result of the positive bias of XBT probes. On the other hand, we note that the global heat content calculated from corrected XBTs is very close to that calculated with the entire corrected database (such agreement is also found when considering specific layers like $0-400 \mathrm{~m}$ or $400-700 \mathrm{~m}$ ). This suggest that XBT data are now globally closer to CTD data. This new correction allow us to find a linear trend of global heat content of $0.32 .10^{22} \mathrm{~J} /$ year between 1970 and 2008. Of

\section{OSD}

$8,291-320,2011$

\section{Empirical correction of XBT fall rate and its impact on heat content analysis}

M. Hamon et al.

Title Page

Abstract Introduction

Conclusions

Tables

References

Figures

14

$\rightarrow 1$

4

Back

Close

Printer-friendly Version

Interactive Discussion 
course, this is strongly dependent on the assumption to fill missing boxes with the annual anomaly for that year, as much southern hemisphere boxes were not sampled in the early periods.

\section{Conclusions}

5 We had to consider 6 different XBT classes to compute a globally second order correction on depth. We chose to separate XBTS and XBTD mostly related to T4 and T7 during the study period. We also separate XBTs deployed in cold or warm water (colder or warmer than $10^{\circ}$ on average between the surface and $200 \mathrm{~m}$ ) due to the dependence of temperature on the behavior of the XBT probes. A parabolic correc10 tion was not sufficient, and it was necessary to apply offsets: One thermal offset only depending on the XBT type to apply to the temperature profiles and a second one, a depth offset. Although we adopt a global perspective, we separated XBTs launched in the western Pacific basin between 1968 and 1985 because of their particular behavior. Our empirical approach does not attempt to found the reasons why those probes have 15 a particular behavior but doing this exception allows to increase the robustness of our global correction. This specific case has also been discussed in W08. They found that the depth error at $400 \mathrm{~m}$ was almost similar between the different basins except for the western Pacific region. As we also show here, they identify a regional negative error.

Furthermore, the thermal offset can be compared to the results obtained by Gouret20 ski and Reseghetti (2010). Our analysis detects an offset almost two times smaller than theirs. This distinction is probably due to our selection criteria which is more stringent. We selected fewer profiles but only those with a thermal gradient lower than $0.0025^{\circ} \mathrm{m}-1$, whereas their upper limit is $0.005^{\circ} \mathrm{m}-1$. Despite the lower total number of profiles selected, the calculation of the offset remains statistically accurate.

25 We corrected the MBT database with the same methodology to obtain a entire corrected database. We were able to compute a revised $0-700 \mathrm{~m}$ heat content and a corresponding estimate of a new linear trend. These calculations agree with other
OSD

8, 291-320, 2011

\section{Empirical correction of XBT fall rate and its impact on heat content analysis}

M. Hamon et al.

Title Page

Abstract Introduction

Conclusions

Tables

References

Figures

14

4

Back

Close Full Screen / Esc

Printer-friendly Version

Interactive Discussion

$>$ I

$>$

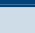


recent papers, thus supporting that the anomalous increase of heat content during the 70's originated from uncorrected XBT biases. It is now necessary to perform a more detailed analysis to highlight the potential gain of such a new correction on an entire database.

5 Acknowledgements. We thank Karina Von schuckmann, Clement de Boyer Montegut and Cecile Cabanes for the useful comments and discussions during the preparation of this manuscript. Mathieu Hamon work is funded by IFREMER and Meteo France as part of a Coriolis Phd Grant.

\section{References}

10 Gouretski, V. and Koltermann, K.: How much is the ocean really warming? Geophys. Res. Lett., 34, L01610, doi:10.1029/2006GL027834, 2007.

Gouretski, V. and Reseghetti, F.: On depth and temperature biases in bthythermograph data: Development of a new correction scheme based on analysis of a global ocean database, Deep-Sea Res. Pt. I, 57, 812-833, 2010.

15 Hanawa, K., Rual, P., Bailey, R., Sy, A., and Szabados, M.: A new depth-time equation for Sippican or TSK T-7, T-6 and T-4 expendable bathythermographs (XBT), 1995.

Levitus S., Antonov, J., and Boyer, T.: Warming of the world ocean, 1955-2003, Geophys. Res. Lett., 32, L02604, doi:10.1029/2004GL021592, 2005.

Levitus, S., Antonov, J., Boyer, T., Locamini, R. A., Garcia, H. E., and Mishonov, A. V.: Global ocean heat content 1955-2008 in light of recently revealed instrumentation problems, Geophys. Res. Lett., 36, L07608, doi:10.1029/2008GL037155, 2009.

Reseghetti, F., Borghini, M., and Manzella, G. M. R.: Factors affecting the quality of XBT data results of analyses on profiles from the Western Mediterranean Sea, Ocean Sci., 3, 59-75, doi:10.5194/os-3-59-2007, 2007.

Seaver, G. A. and, Kuleshov, S.: Experimental and Analytical Error of the Expendable Bathythermograph, J. Phys. Oceanogr., 12, 592-600, 1982.

Thadathil, P., Gosh, A. K., and Muraleedharan, P. M.: An evaluation of XBT depth equations for the Indian Ocean, Deep-Sea Res. Pt. I, 45, 819-827, 1997.

Thadathil, P., Gosh, A. K., Pattanaik, J., and Ratnakaran, L.: A Quality-Control Procedure for

\section{OSD}

$8,291-320,2011$

\section{Empirical correction of XBT fall rate and its impact on heat content analysis}

M. Hamon et al.

\section{Title Page}

\section{Abstract} Introduction

Conclusions

References

Tables Figures

14

$>1$

4

Back

Close

Printer-friendly Version

Interactive Discussion 
Surface and Surface Layer Inversion in the XBT Data Archive from the Indian Ocean, J. Atmos. Oceanic Technol., 16, 980-982, 1998.

Thadathil, P., Saran, A. K., Gopalakrishna, V. V., Vethamony, P., Araligidad, N., Bailey, R.: XBT Fall Rate in Waters of Extreme Temperature: A Case Study in the Antarctic Ocean, J. Atmos. Ocean. Technol., 19, 391-396, 2002.

Wijffels, S. E., Willis, J., Domingues, C. M., Barker, P., White, N. J., Gronell, A., Ridgway, K., Church, J. A.: Changing Expendable Bathythermograph Fall Rates and Their Impact on Estimates of Thermosteric Sea Level Rise, J. Climate, 21, 5657-5672, doi:10.1175/2008JCLI2290.1, 2008.

\section{OSD}

8, 291-320, 2011

\section{Empirical correction of XBT fall rate and its impact on heat content analysis}

M. Hamon et al.

Title Page

Abstract Introduction

Conclusions

References

Tables

Figures

14

4

Back

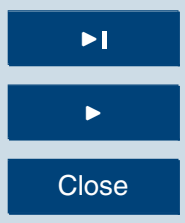

Full Screen / Esc

Printer-friendly Version

Interactive Discussion 

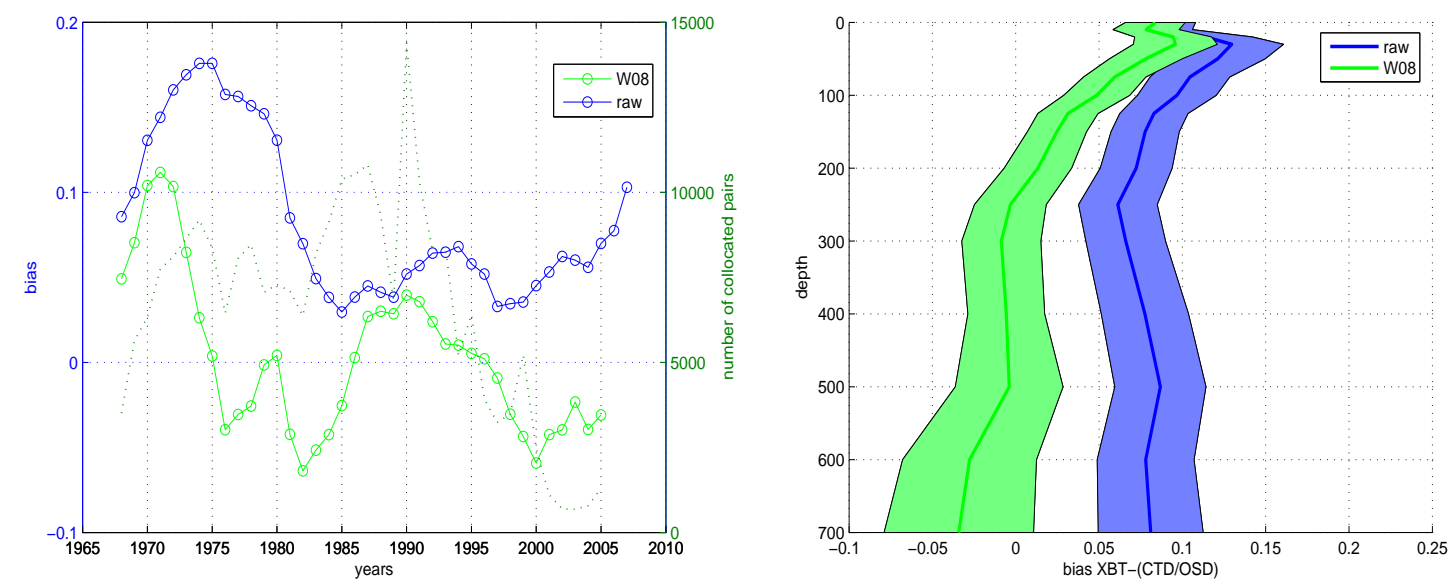

OSD

8, 291-320, 2011

\section{Empirical correction of XBT fall rate and its impact on heat content analysis}

M. Hamon et al.

\section{Title Page}

Abstract

Conclusions

Tables

14

Back

Introduction

References

Figures

Fig. 1. Evolution of XBT-CTD 0/700 m median raw bias (blue) and corrected by W08 (green) integrated between 0 and $700 \mathrm{~m}$. The number of yearly collocated pairs is indicated with the green dotted line (left). Median raw bias (blue) and corrected by W08 (green) as a function of depth averaged over the study period (right). The width represents the standard deviation of the annual median bias.

\section{Full Screen / Esc}

Printer-friendly Version

Interactive Discussion 

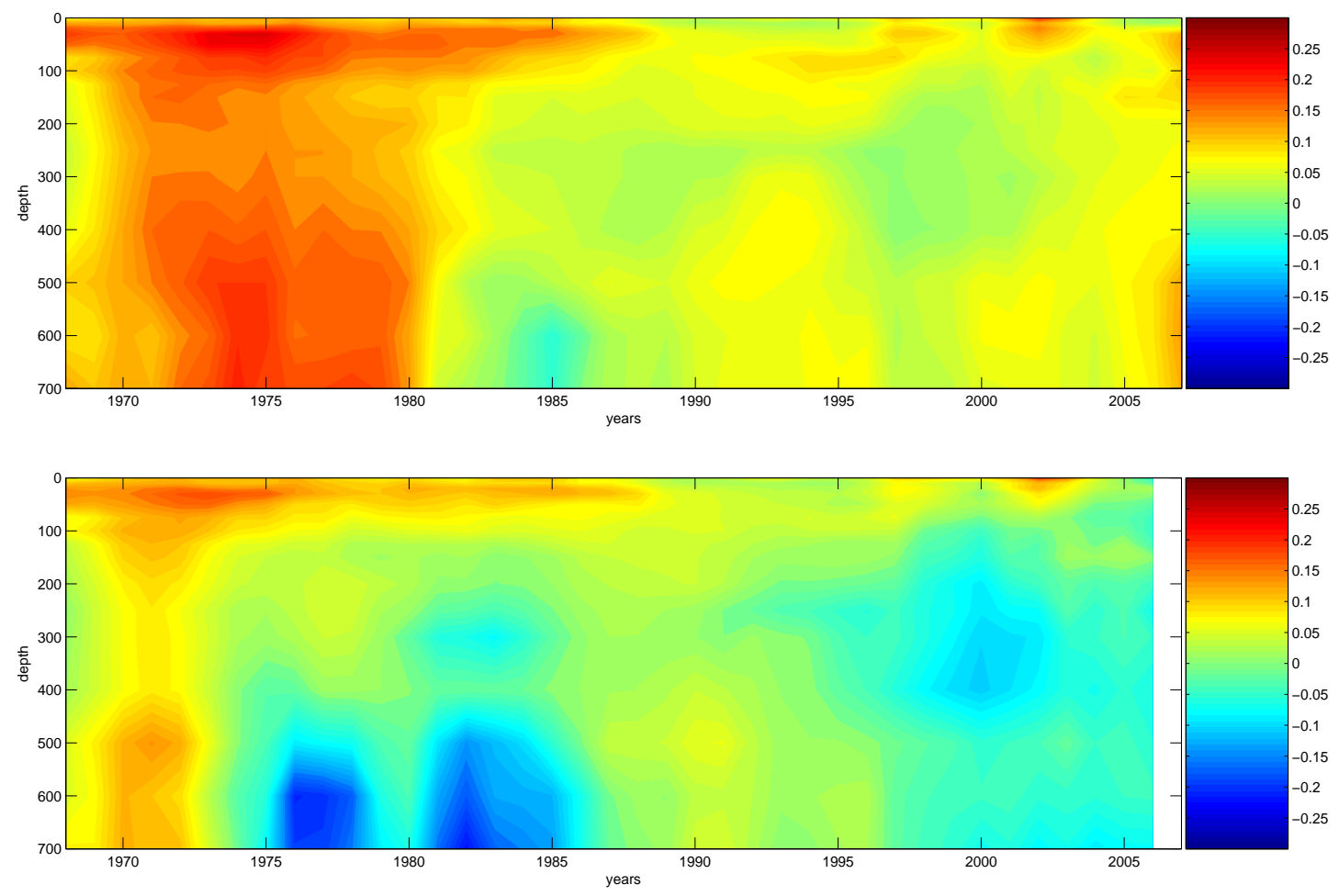

Fig. 2. Evolution of XBT-CTD median raw bias (above) and corrected by W08 (under) as a function of depth and time.
OSD

$8,291-320,2011$

\section{Empirical correction of XBT fall rate and its impact on heat content analysis}

M. Hamon et al.

Title Page

Abstract

Introduction

Conclusions

References

Tables

Figures

14

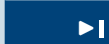

4

Back

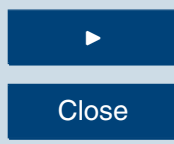

Full Screen / Esc

Printer-friendly Version

Interactive Discussion 


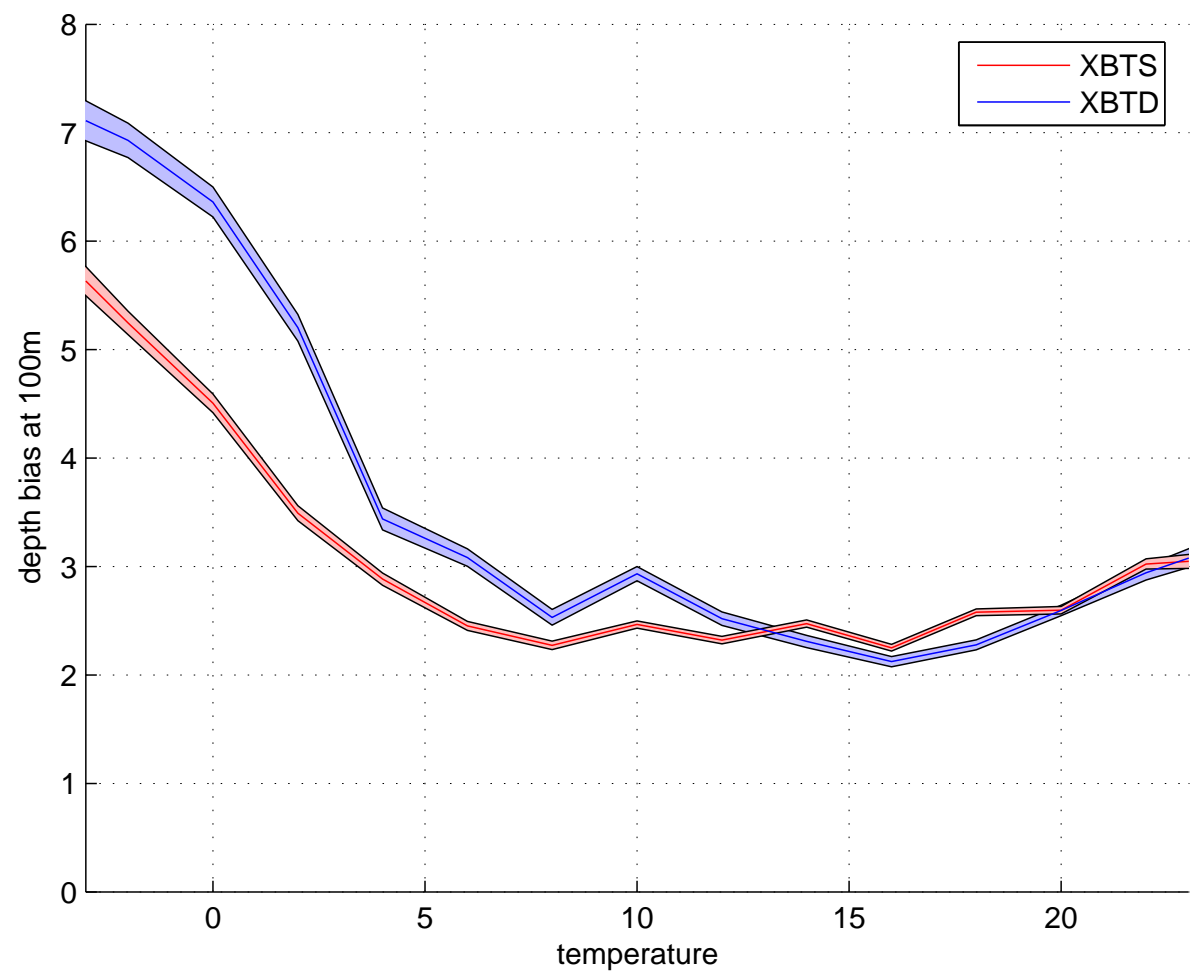

Fig. 3. Median XBT-CTD depth bias at $100 \mathrm{~m}$ depth as a function of the integrated temperature between 0 and $200 \mathrm{~m}$ depth for XBTS (red) and XBTD (blue). The standard deviation divided by the square root of the number of selected pairs in each class is represented with the colored area.
OSD

8, 291-320, 2011

\section{Empirical correction of XBT fall rate and its impact on heat content analysis}

M. Hamon et al.

Title Page

Abstract Introduction

Conclusions

References

Tables

Figures

14

$\rightarrow 1$

4

Back

Close

Full Screen / Esc

Printer-friendly Version

Interactive Discussion 


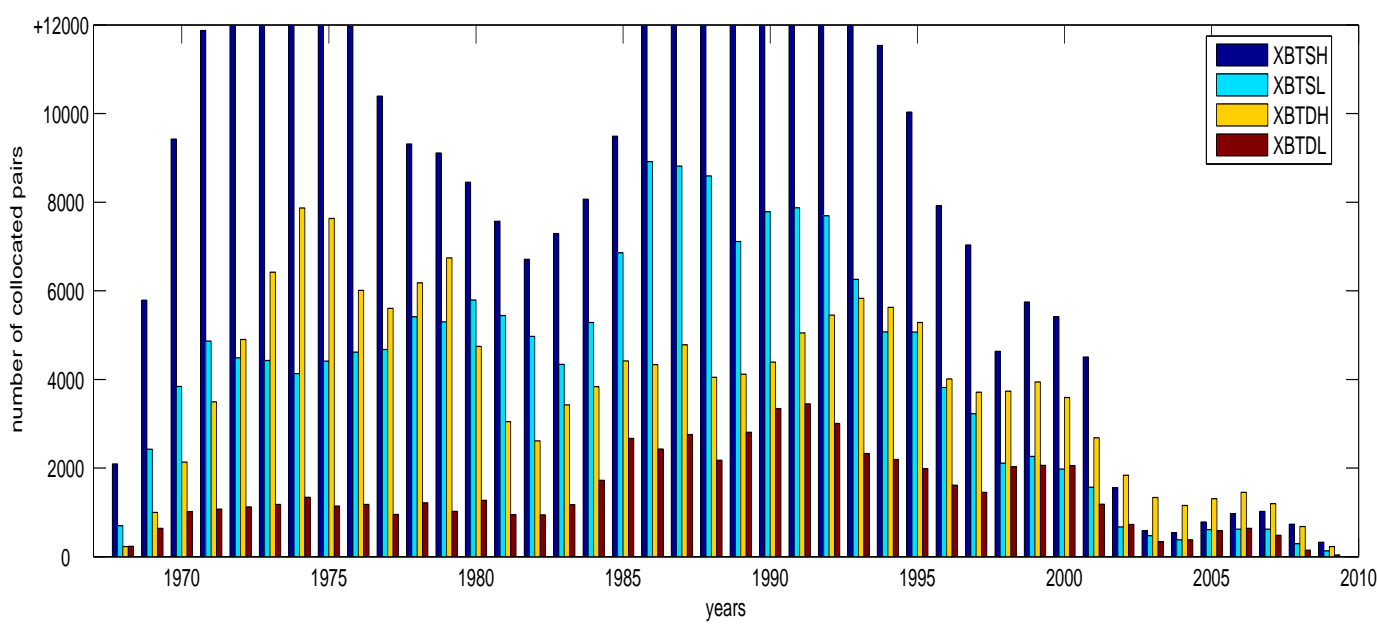

Fig. 4. Number of colocated pairs for the four classes of XBT function of time. XBTS(D)H/XBTS(D)L correspond to shallow (deep) XBTs deployed in high and klow temperatures.

OSD

8, 291-320, 2011

\section{Empirical correction of XBT fall rate and its impact on heat content analysis}

M. Hamon et al.

Title Page

Abstract

Conclusions

Tables

14

4

Back

Full Screen / Esc

Printer-friendly Version

Interactive Discussion 


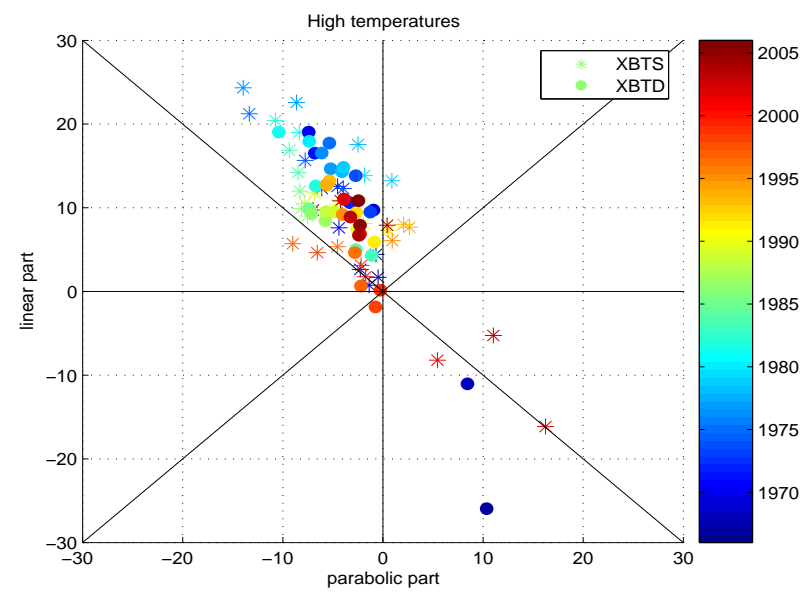

OSD

8, 291-320, 2011

\section{Empirical correction of XBT fall rate and its impact on heat content analysis}

M. Hamon et al.

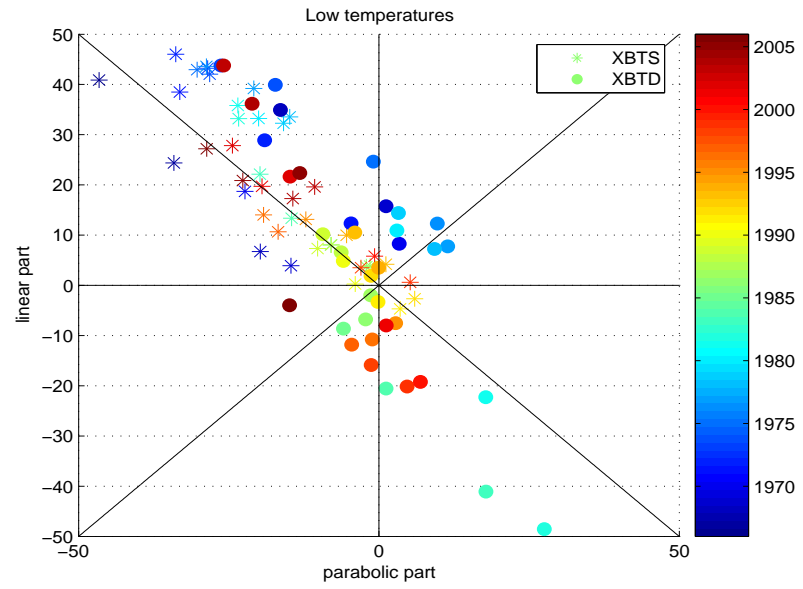

Title Page

Abstract Introduction

Conclusions

References

Tables

Figures

14

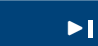

4

Back

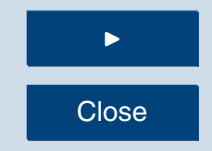

Full Screen / Esc

Printer-friendly Version

Fig. 5. Linear part (coefficient $B(t))$ an a function of parabolic part $(A(t) \times 400)$ at $400 \mathrm{~m}$ depth for XBTS (large dots) and XBTD (stars). The upper figure represents XBTs deployed at high temperatures and at the bottom, XBTs deployed at low temperatures. Years are indicated with the colorbar.

308

Interactive Discussion

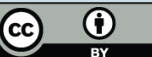




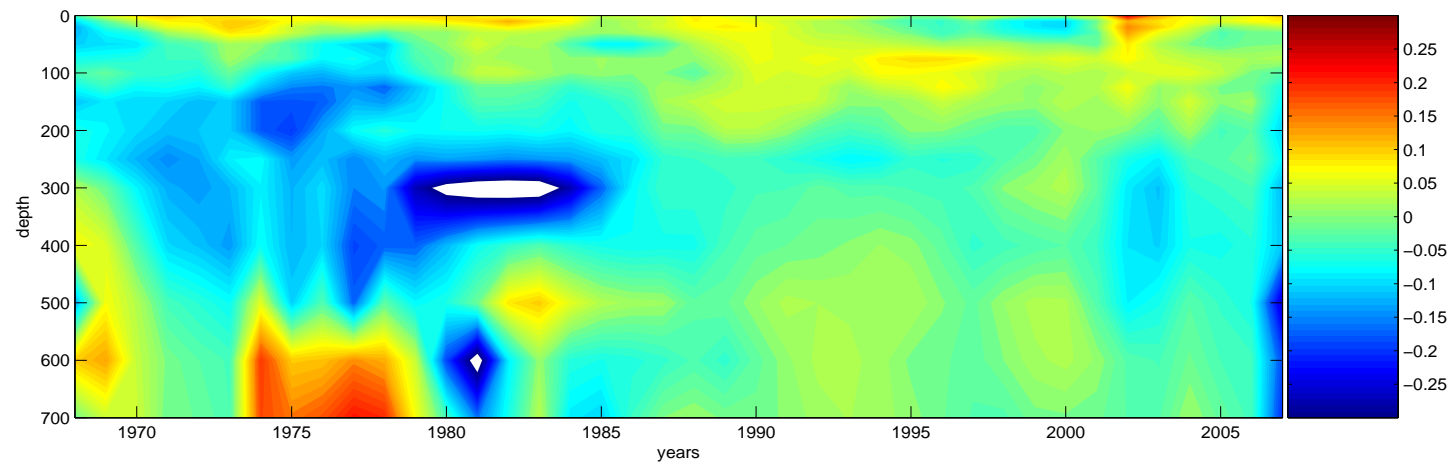

Fig. 6. Evolution of XBT-CTD median bias deployed in the western Pacific basin (the region is bounded by $180^{\circ} \mathrm{E}$ and $20^{\circ} \mathrm{S}$ ) between 1968 and 1985 , corrected by a global parabolic correction, as a function of depth and time.
OSD

8, 291-320, 2011

\section{Empirical correction of XBT fall rate and its impact on heat content analysis}

M. Hamon et al.

\section{Title Page}

Abstract

Introduction

Conclusions

References

Tables

Figures

14

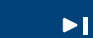

Back

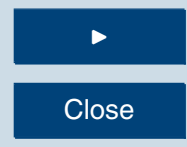

Full Screen / Esc

Printer-friendly Version

Interactive Discussion 


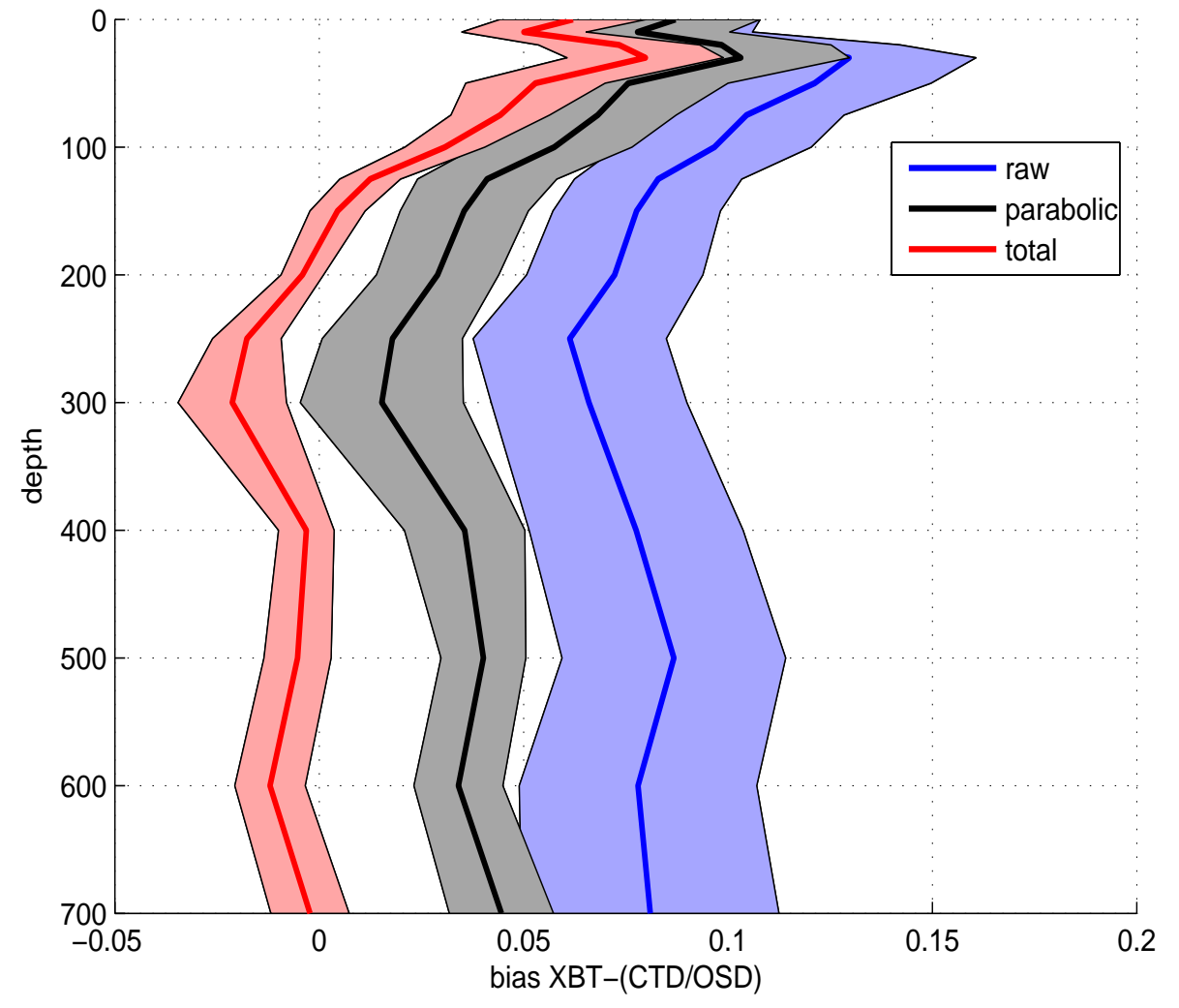

Fig. 7. Median raw bias (green), corrected by the parabolic correction (blue) and corrected by a parabolic correction added an offset (red) as afunction of depth averaged over the study period $1968 / 2007$.

\section{OSD}

\section{8, 291-320, 2011}

\section{Empirical correction of XBT fall rate and its impact on heat content analysis}

M. Hamon et al.

Title Page

Abstract

Introduction

Conclusions

References

Tables

Figures

14

4

Back

Close

Full Screen / Esc

Printer-friendly Version

Interactive Discussion 

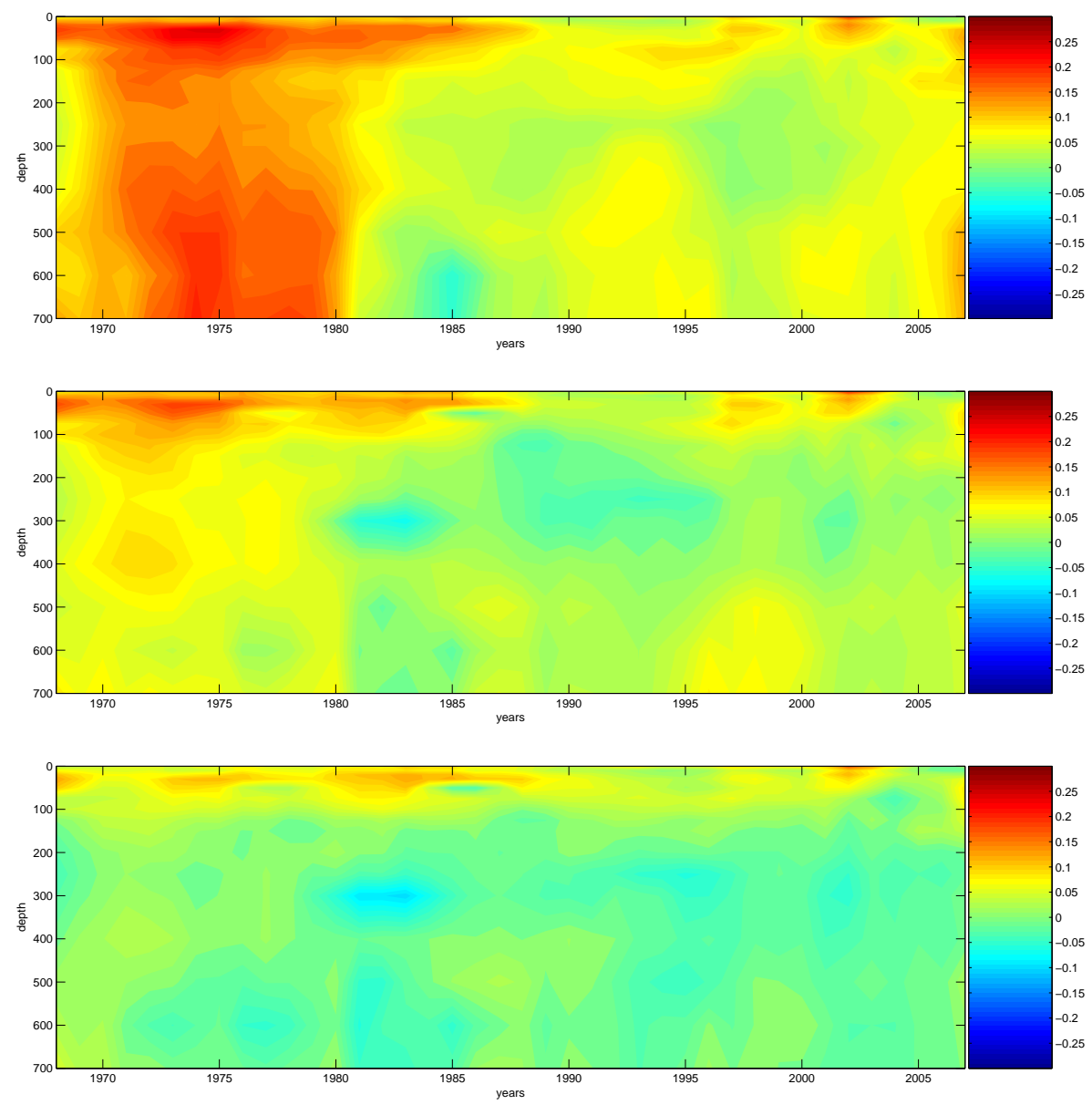

Fig. 8. Evolution of XBT-CTD median raw bias (above) and corrected by a parabolic correction (middle) and corrected by a parabolic correction added an offset (under) as a function of depth and time.

OSD

8, 291-320, 2011

\section{Empirical correction of $X B T$ fall rate and its impact on heat content analysis}

M. Hamon et al.

Title Page

Abstract

Introduction

Conclusions

References

Tables

Figures

14

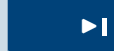

4

Back

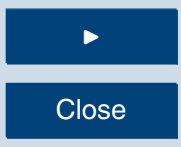

Full Screen / Esc

Printer-friendly Version

Interactive Discussion 

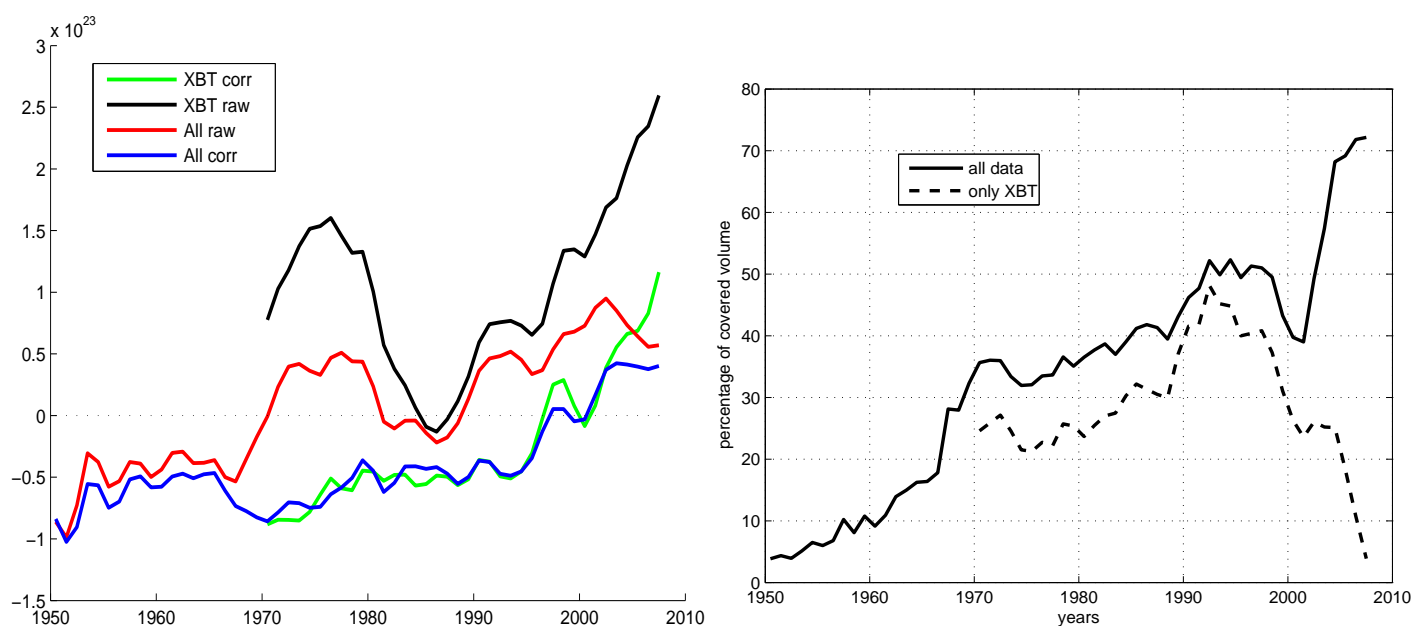

Fig. 9. Integrated heat content between the surface and $700 \mathrm{~m}$ depth calculated using the entire raw dataset (red), the entire corrected dataset (blue), and only using raw XBTs (black) and corrected XBTs (green) function of years (left). Percentage of the oceanic volume covered by $4^{\circ} \times 8^{\circ}$ boxes including all data (full line) and only XBT data (dotted line) (right).

\section{Empirical correction of XBT fall rate and its impact on heat content analysis}

M. Hamon et al.

\section{Title Page}

\section{Abstract}

Introduction

Conclusions

References

Tables

Figures

14

4

Back

Close

Full Screen / Esc

Printer-friendly Version

Interactive Discussion 
Table 1. Thermal offset as a function of time for XBTS and XBTD.

\section{OSD}

\begin{tabular}{clr}
\hline Year & $T_{\text {offset }} D$ & $T_{\text {offset }} S$ \\
\hline 1968 & 0.008 & 0.067 \\
1969 & 0.013 & 0.068 \\
1970 & 0.023 & 0.064 \\
1971 & 0.036 & 0.062 \\
1972 & 0.045 & 0.061 \\
1973 & 0.052 & 0.064 \\
1974 & 0.058 & 0.067 \\
1975 & 0.059 & 0.073 \\
1976 & 0.058 & 0.077 \\
1977 & 0.057 & 0.079 \\
1978 & 0.059 & 0.078 \\
1979 & 0.064 & 0.073 \\
1980 & 0.063 & 0.065 \\
1981 & 0.050 & 0.053 \\
1982 & 0.039 & 0.047 \\
1983 & 0.029 & 0.041 \\
1984 & 0.018 & 0.038 \\
1985 & 0.012 & 0.032 \\
1986 & 0.017 & 0.030 \\
1987 & 0.021 & 0.024 \\
1988 & 0.018 & 0.018 \\
1989 & 0.014 & 0.009 \\
1990 & 0.014 & 0.003 \\
1991 & 0.018 & -0.002 \\
1992 & 0.022 & -0.004 \\
1993 & 0.031 & -0.004 \\
1994 & 0.041 & -0.003 \\
1995 & 0.052 & -0.002 \\
1996 & 0.057 & 0.000 \\
1997 & 0.059 & 0.001 \\
1998 & 0.060 & -0.002 \\
1999 & 0.057 & -0.004 \\
2000 & 0.046 & -0.009 \\
2001 & 0.040 & -0.003 \\
2002 & 0.038 & -0.001 \\
2003 & 0.036 & 0.014 \\
2004 & 0.036 & 0.023 \\
2005 & 0.038 & 0.031 \\
2006 & 0.039 & 0.022 \\
2007 & 0.033 & 0.014 \\
\hline & 313 & \\
& & \\
& &
\end{tabular}

\section{8, 291-320, 2011}

\section{Empirical correction of XBT fall rate and its impact on heat content analysis}

M. Hamon et al.

Title Page

Abstract

Conclusions

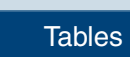

Tables

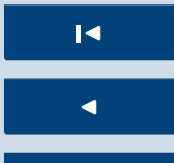

Back

Full Screen / Esc

Printer-friendly Version

Interactive Discussion 
OSD

8, 291-320, 2011

Table 2. Thermal offset as a function of time for XBTs deployed in the west Pacific basin between 1968 and 1985.

\begin{tabular}{cr}
\hline Year & $T_{\text {offset }}$ \\
\hline 1968 & 0.048 \\
1969 & 0.041 \\
1970 & 0.039 \\
1971 & 0.029 \\
1972 & 0.031 \\
1973 & 0.022 \\
1974 & 0.010 \\
1975 & -0.004 \\
1976 & -0.013 \\
1977 & -0.020 \\
1978 & -0.019 \\
1979 & -0.011 \\
1980 & -0.004 \\
1981 & -0.002 \\
1982 & -0.003 \\
1983 & 0.002 \\
1984 & 0.008 \\
1985 & 0.017 \\
\hline
\end{tabular}

\section{Empirical correction of XBT fall rate and its impact on heat content analysis}

M. Hamon et al.

\section{Title Page}

\section{Abstract}

Introduction

Conclusions

References

Tables

Figures

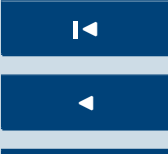

Back

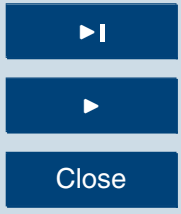

Full Screen / Esc

Printer-friendly Version

Interactive Discussion 
Table 3. Coefficients of the parabolic correction and the depth offset for XBTD deployed in high temperatures.

\begin{tabular}{|c|c|c|c|}
\hline Year & $A_{\mathrm{DH}}$ & $B_{\mathrm{DH}}$ & Offset $_{D H}$ \\
\hline 1968 & 0.000065 & -0.065 & 1.2 \\
\hline 1969 & 0.000053 & -0.028 & 0.6 \\
\hline 1970 & -0.000006 & 0.024 & 0.1 \\
\hline 1971 & -0.000046 & 0.048 & 0.3 \\
\hline 1972 & -0.000043 & 0.041 & 0.7 \\
\hline 1973 & -0.000021 & 0.027 & 0.6 \\
\hline 1974 & -0.000008 & 0.024 & 0.2 \\
\hline 1975 & -0.000017 & 0.035 & 0.0 \\
\hline 1976 & -0.000033 & 0.044 & -0.1 \\
\hline 1977 & -0.000038 & 0.041 & -0.5 \\
\hline 1978 & -0.000033 & 0.037 & -0.8 \\
\hline 1979 & -0.000026 & 0.036 & -0.8 \\
\hline 1980 & -0.000025 & 0.037 & -0.5 \\
\hline 1981 & -0.000046 & 0.045 & -0.2 \\
\hline 1982 & -0.000065 & 0.048 & 0.0 \\
\hline 1983 & -0.000042 & 0.032 & 0.0 \\
\hline 1984 & -0.000007 & 0.011 & 0.0 \\
\hline 1985 & -0.000017 & 0.013 & 0.2 \\
\hline 1986 & -0.000046 & 0.025 & 0.8 \\
\hline 1987 & -0.000045 & 0.023 & 1.5 \\
\hline 1988 & -0.000036 & 0.021 & 1.7 \\
\hline 1989 & -0.000036 & 0.024 & 1.1 \\
\hline 1990 & -0.000030 & 0.024 & 0.4 \\
\hline 1991 & -0.000016 & 0.019 & 0.0 \\
\hline 1992 & -0.000005 & 0.015 & -0.3 \\
\hline 1993 & -0.000017 & 0.024 & -1.0 \\
\hline 1994 & -0.000033 & 0.033 & -1.4 \\
\hline 1995 & -0.000035 & 0.032 & -1.2 \\
\hline 1996 & -0.000025 & 0.023 & -0.6 \\
\hline 1997 & -0.000018 & 0.012 & -0.1 \\
\hline 1998 & -0.000014 & 0.002 & 0.6 \\
\hline 1999 & -0.000005 & -0.005 & 1.1 \\
\hline 2000 & -0.000002 & 0.001 & 0.8 \\
\hline 2001 & -0.000014 & 0.017 & 0.1 \\
\hline 2002 & -0.000024 & 0.028 & -0.2 \\
\hline 2003 & -0.000024 & 0.028 & -0.3 \\
\hline 2004 & -0.000020 & 0.022 & -0.5 \\
\hline 2005 & -0.000015 & 0.017 & -0.7 \\
\hline 2006 & -0.000014 & 0.020 & -0.4 \\
\hline 2007 & -0.000015 & 0.027 & 0.0 \\
\hline
\end{tabular}

OSD

\section{8, 291-320, 2011}

\section{Empirical correction of XBT fall rate and its impact on heat content analysis}

M. Hamon et al.

Title Page

Abstract

Introduction

Conclusions

References

Tables

Figures

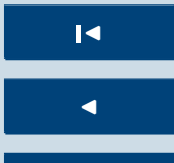

Back

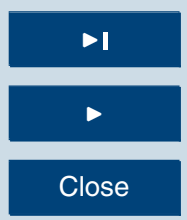

Full Screen / Esc

Printer-friendly Version

Interactive Discussion 
Table 4. Coefficients of the parabolic correction and the depth offset for XBTD deployed in low temperatures.

\begin{tabular}{rrrr}
\hline Year & $A_{\mathrm{DL}}$ & $B_{\mathrm{DL}}$ & Offset $_{\mathrm{DL}}$ \\
\hline 1968 & -0.000231 & 0.129 & 0.7 \\
1969 & -0.000102 & 0.087 & 1.7 \\
1970 & 0.000007 & 0.039 & 2.4 \\
1971 & 0.000021 & 0.021 & 1.9 \\
1972 & -0.000029 & 0.031 & 1.2 \\
1973 & -0.000119 & 0.072 & 1.7 \\
1974 & -0.000164 & 0.110 & 2.4 \\
1975 & -0.000108 & 0.100 & 2.6 \\
1976 & -0.000006 & 0.062 & 2.9 \\
1977 & 0.000061 & 0.031 & 2.5 \\
1978 & 0.000072 & 0.019 & 1.2 \\
1979 & 0.000058 & 0.018 & 0.1 \\
1980 & 0.000020 & 0.036 & 0.4 \\
1981 & 0.000019 & 0.027 & 0.9 \\
1982 & 0.000111 & -0.056 & -1.0 \\
1983 & 0.000172 & -0.121 & -3.3 \\
1984 & 0.000111 & -0.103 & -2.8 \\
1985 & 0.000007 & -0.051 & -0.7 \\
1986 & -0.000037 & -0.021 & 1.0 \\
1987 & -0.000014 & -0.017 & 2.1 \\
1988 & -0.000008 & -0.005 & 2.5 \\
1989 & -0.000039 & 0.017 & 1.4 \\
1990 & -0.000058 & 0.025 & -0.2 \\
1991 & -0.000037 & 0.012 & -0.7 \\
1992 & -0.000001 & -0.008 & -0.2 \\
1993 & -0.000008 & 0.005 & 0.0 \\
1994 & -0.000025 & 0.026 & 0.0 \\
1995 & -0.000000 & 0.009 & 0.0 \\
1996 & 0.000017 & -0.019 & 0.2 \\
1997 & -0.000007 & -0.027 & 0.9 \\
1998 & -0.000028 & -0.029 & 1.7 \\
1999 & -0.000008 & -0.040 & 2.2 \\
2000 & 0.000029 & -0.050 & 1.6 \\
2001 & 0.000043 & -0.048 & 0.1 \\
2002 & 0.000008 & -0.020 & -1.4 \\
2003 & -0.000093 & 0.054 & -1.9 \\
2004 & -0.000162 & 0.110 & -1.6 \\
2005 & -0.000132 & 0.090 & -1.1 \\
2006 & -0.000082 & 0.056 & -0.4 \\
2007 & -0.000093 & -0.010 & 1.7 \\
\hline & & & \\
& & 316 & \\
\hline
\end{tabular}

OSD

\section{8, 291-320, 2011}

\section{Empirical correction of XBT fall rate and its impact on heat content analysis}

M. Hamon et al.

Title Page

Abstract

Introduction

Conclusions

References

Tables

Figures
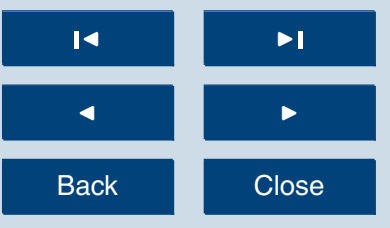

Back

Close

Full Screen / Esc

Printer-friendly Version

Interactive Discussion 
Table 5. Coefficients of the parabolic correction and the depth offset for XBTS deployed in high temperatures.

\begin{tabular}{rrrr}
\hline Year & $A_{\mathrm{SH}}$ & $B_{\mathrm{SH}}$ & Offset $_{\mathrm{SH}}$ \\
\hline 1968 & -0.000003 & 0.004 & -1.5 \\
1969 & -0.000009 & 0.002 & -0.8 \\
1970 & -0.000014 & 0.007 & 0.0 \\
1971 & -0.000027 & 0.019 & 0.6 \\
1972 & -0.000038 & 0.031 & 1.0 \\
1973 & -0.000028 & 0.031 & 1.0 \\
1974 & -0.000025 & 0.031 & 0.3 \\
1975 & -0.000048 & 0.039 & -0.3 \\
1976 & -0.000083 & 0.053 & -0.5 \\
1977 & -0.000087 & 0.061 & -0.6 \\
1978 & -0.000054 & 0.057 & -1.1 \\
1979 & -0.000016 & 0.044 & -1.5 \\
1980 & 0.000006 & 0.033 & -1.5 \\
1981 & -0.000012 & 0.035 & -1.2 \\
1982 & -0.000052 & 0.048 & -1.0 \\
1983 & -0.000067 & 0.051 & -0.9 \\
1984 & -0.000058 & 0.042 & -0.8 \\
1985 & -0.000053 & 0.035 & -0.6 \\
1986 & -0.000052 & 0.030 & -0.5 \\
1987 & -0.000051 & 0.025 & -1.0 \\
1988 & -0.000047 & 0.022 & -2.1 \\
1989 & -0.000049 & 0.026 & -2.5 \\
1990 & -0.000043 & 0.029 & -2.0 \\
1991 & -0.000028 & 0.026 & -1.4 \\
1992 & -0.000012 & 0.020 & -1.2 \\
1993 & 0.000003 & 0.018 & -1.2 \\
1994 & 0.000013 & 0.020 & -0.8 \\
1995 & 0.000016 & 0.019 & -0.3 \\
1996 & 0.000006 & 0.015 & 0.0 \\
1997 & -0.000028 & 0.013 & -0.2 \\
1998 & -0.000056 & 0.014 & -0.6 \\
1999 & -0.000041 & 0.012 & -1.0 \\
2000 & -0.000014 & 0.008 & -1.0 \\
2001 & -0.000011 & 0.004 & -0.6 \\
2002 & 0.000034 & -0.021 & -0.1 \\
2003 & 0.000102 & -0.040 & 0.2 \\
2004 & 0.000069 & -0.013 & -0.1 \\
2005 & 0.000003 & 0.020 & -0.9 \\
2006 & -0.000026 & 0.027 & -1.2 \\
2007 & -0.000044 & 0.024 & -0.8 \\
\hline & & & \\
& & 31 & \\
\end{tabular}

\section{OSD}

\section{8, 291-320, 2011}

\section{Empirical correction of XBT fall rate and its impact on heat content analysis}

M. Hamon et al.

Title Page

Abstract

Conclusions

Tables

References

Figures

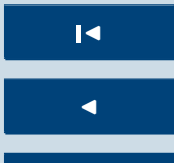

Back

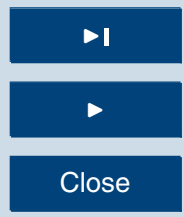

Full Screen / Esc

Printer-friendly Version

Interactive Discussion 
Table 6. Coefficients of the parabolic correction and the depth offset for XBTS deployed in low temperatures.

\begin{tabular}{rrrr}
\hline Year & $A_{\mathrm{SL}}$ & $B_{\mathrm{SL}}$ & Offset $_{\mathrm{SL}}$ \\
\hline 1968 & -0.000213 & 0.061 & 0.2 \\
1969 & -0.000123 & 0.017 & 0.5 \\
1970 & -0.000092 & 0.010 & 1.1 \\
1971 & -0.000139 & 0.047 & 2.2 \\
1972 & -0.000207 & 0.096 & 3.2 \\
1973 & -0.000211 & 0.115 & 3.8 \\
1974 & -0.000178 & 0.108 & 3.7 \\
1975 & -0.000176 & 0.105 & 3.2 \\
1976 & -0.000189 & 0.107 & 2.5 \\
1977 & -0.000179 & 0.109 & 1.4 \\
1978 & -0.000130 & 0.098 & 0.4 \\
1979 & -0.000093 & 0.084 & -0.2 \\
1980 & -0.000099 & 0.081 & -0.7 \\
1981 & -0.000125 & 0.083 & -0.9 \\
1982 & -0.000147 & 0.090 & -0.8 \\
1983 & -0.000146 & 0.083 & -0.5 \\
1984 & -0.000124 & 0.055 & -0.5 \\
1985 & -0.000091 & 0.034 & -0.4 \\
1986 & -0.000050 & 0.020 & -0.3 \\
1987 & -0.000013 & 0.009 & -0.3 \\
1988 & -0.000009 & 0.010 & -0.6 \\
1989 & -0.000050 & 0.020 & -1.4 \\
1990 & -0.000064 & 0.018 & -1.8 \\
1991 & -0.000025 & 0.001 & -1.4 \\
1992 & 0.000022 & -0.012 & -0.7 \\
1993 & 0.000037 & -0.007 & -0.4 \\
1994 & 0.000007 & 0.011 & -0.5 \\
1995 & -0.000034 & 0.025 & -0.8 \\
1996 & -0.000076 & 0.033 & -1.2 \\
1997 & -0.000120 & 0.035 & -0.9 \\
1998 & -0.000105 & 0.027 & -0.2 \\
1999 & -0.000019 & 0.009 & 0.0 \\
2000 & 0.000033 & 0.002 & 0.0 \\
2001 & -0.000004 & 0.015 & -0.5 \\
2002 & -0.000122 & 0.049 & -1.2 \\
2003 & -0.000152 & 0.070 & -1.2 \\
2004 & -0.000067 & 0.049 & -1.3 \\
2005 & -0.000090 & 0.043 & -2.0 \\
2006 & -0.000142 & 0.052 & -2.5 \\
2007 & -0.000179 & 0.068 & -1.7 \\
\hline & & & \\
& & \\
1918
\end{tabular}

OSD

\section{8, 291-320, 2011}

\section{Empirical correction of XBT fall rate and its impact on heat content analysis}

M. Hamon et al.

Title Page

Abstract

Introduction

Conclusions

References

Tables

Figures

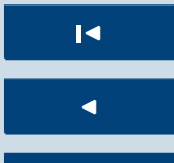

Back

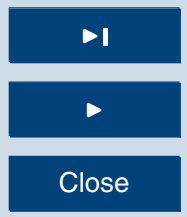

Full Screen / Esc

Printer-friendly Version

Interactive Discussion 
Table 7. Coefficients of the parabolic correction and the depth offset for XBTD deployed in west Pacific basin between 1968 and 1985.

\begin{tabular}{rrrr}
\hline Year & $A$ & $B$ & Offset \\
\hline 1968 & 0.000000 & 0.000 & 0.0 \\
1969 & 0.000000 & 0.000 & 0.0 \\
1970 & 0.000000 & 0.000 & 0.0 \\
1971 & 0.000000 & 0.000 & 0.0 \\
1972 & 0.000124 & -0.096 & 4.6 \\
1973 & 0.000059 & -0.019 & 3.2 \\
1974 & 0.000148 & -0.088 & 4.6 \\
1975 & 0.000200 & -0.029 & 5.0 \\
1976 & 0.000041 & -0.015 & 2.4 \\
1977 & 0.000012 & 0.023 & 0.4 \\
1978 & -0.000054 & 0.050 & 0.3 \\
1979 & 0.000035 & 0.020 & 0.3 \\
1980 & 0.000012 & 0.015 & 0.2 \\
1981 & 0.000054 & -0.003 & -0.2 \\
1982 & 0.000072 & -0.021 & -1.7 \\
1983 & -0.000089 & 0.057 & -3.4 \\
1984 & -0.000065 & 0.067 & -4.0 \\
1985 & -0.000044 & 0.033 & -4.0 \\
\hline
\end{tabular}

\section{Empirical correction of XBT fall rate and its impact on heat content analysis}

M. Hamon et al.

\section{Title Page}

\section{Abstract}

Introduction

Conclusions

References

Tables

Figures
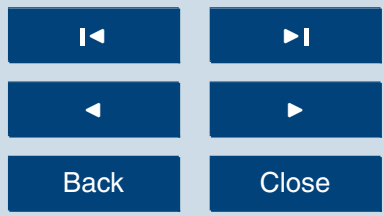

Back

Full Screen / Esc

Printer-friendly Version

Interactive Discussion 
Table 8. Coefficients of the parabolic correction and the depth offset for XBTS deployed in west Pacific basin between 1968 and 1985.

\begin{tabular}{rrrr}
\hline Year & $A$ & $B$ & Offset \\
\hline 1968 & 0.000099 & -0.034 & -2.5 \\
1969 & 0.000044 & -0.013 & -2.1 \\
1970 & -0.000018 & 0.010 & -1.7 \\
1971 & -0.000036 & 0.019 & -1.3 \\
1972 & -0.000008 & 0.017 & -1.1 \\
1973 & 0.000015 & 0.017 & -1.1 \\
1974 & 0.000007 & 0.021 & -1.1 \\
1975 & -0.000030 & 0.034 & -0.9 \\
1976 & -0.000052 & 0.047 & -0.8 \\
1977 & -0.000048 & 0.046 & -0.5 \\
1978 & -0.000049 & 0.042 & -0.1 \\
1979 & -0.000043 & 0.035 & 0.0 \\
1980 & -0.000027 & 0.031 & 0.0 \\
1981 & -0.000012 & 0.025 & 0.0 \\
1982 & 0.000011 & 0.013 & 0.1 \\
1983 & 0.000039 & 0.001 & 0.2 \\
1984 & 0.000058 & -0.004 & 0.2 \\
1985 & 0.000055 & -0.004 & 0.1 \\
\hline
\end{tabular}

\section{Empirical correction of XBT fall rate and its impact on heat content analysis}

M. Hamon et al.

\section{Title Page}

\section{Abstract}

Introduction

Conclusions

References

Tables

Figures
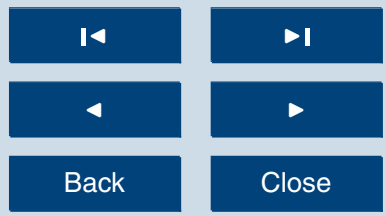

Back

lose

Full Screen / Esc

Printer-friendly Version

Interactive Discussion 